\title{
A Literature Analysis of the Use of Absorptive Capacity Construct in IS Research
}

\author{
Shijia Gao \\ Faculty of Information Technology \\ Monash University \\ Caulfield East, VIC 3145, Australia \\ caddie.gao@monash.edu \\ William Yeoh \\ Department of Information Systems and Business Analytics \\ Deakin University \\ Burwood, VIC 3125 Australia \\ william.yeoh@deakin.edu.au \\ Siew Fan Wong \\ Faculty of Science and Technology \\ Sunway University \\ Selangor 46150 Malaysia \\ siewfanw@sunway.edu.my \\ Rens Scheepers \\ Department of Information Systems and Business Analytics \\ Deakin University \\ Burwood, VIC 3125 Australia \\ rens.scheepers@deakin.edu.au
}

\begin{abstract}
Since the seminal inception of Absorptive Capacity (ACAP) by Cohen and Levinthal (1990), it has been adopted widely in information systems (IS) research. This paper analyzes the use of ACAP in IS research through a literature analysis of ACAP-related papers published in 53 reputable IS journals from 1990 to 2015. Drawing on a review of the evolution of ACAP, the analyses conducted include: 1) descriptive analysis of ACAP in IS papers; 2) domains of ACAP usage; 3) analysis of hypotheses and propositions to show how ACAP is being used to explain
\end{abstract}


various organizational phenomena in IS research; and (4) analysis of the measures to provide insights into the operationalization of ACAP in IS research. Our findings suggest that while the majority of the research correctly conceptualizes ACAP as a capability, various misalignments between ACAP conceptualization, operationalization and measurement, and the level of analysis in the literature continue to do a disservice to the accumulated research in ACAP. The findings and recommendations should help IS researchers to conceptualize and operationalize ACAP appropriately.

Keywords: Absorptive Capacity (ACAP), Literature Analysis, Information Systems (IS) Research, Conceptualization, Measurement 


\section{Introduction}

Since Cohen and Levinthal's (1990) seminal work on Absorptive Capacity, ACAP has become recognized as a key driver of an organization's competitive advantage, and over time ACAP has been re-examined and further developed by other authors. Generally, ACAP is defined as "the ability of a firm to recognize the value of new, external information, assimilate it, and apply it to commercial ends" (Cohen and Levinthal, 1990, p128). With the ubiquitous and pervasive nature of knowledge in organizations, the rapid convergence and diffusion of computing, communications, and content technologies offers organizations significant opportunities to enhance organizational ACAP (Roberts et al., 2012). Zahra and George (2002) acknowledge that while the references to ACAP in the literature are many and varied, there is also much ambiguity in the use of ACAP among different researchers.

ACAP is an important construct in information systems (IS) research, as evidenced by the large number of citations in IS academic journals. Organizations are now allocating more expenditure to human resource enhancement, software and ICT infrastructure with the aim of developing the absorptive, retentive, and exploitative capabilities to use acquired knowledge. These developments are enabling organizations to achieve and sustain their competitive advantage (Armstrong and Sambamurthy, 1999). This applies both to an organization's understanding of its operations, in terms of process and the management of its product and service offerings, as well as to its understanding of the "state of the art" in IS. Being close to the cutting edge of IS through continual research and investment in technology assets and capabilities thus enables an organization to continually learn and absorb external knowledge in order to improve its ACAP. Understanding how researchers observe and explain the extent of organizational ACAP and its relationship with various aspects of IS is critical to the ability to determine methods and constructs that organizations can utilize to develop this capability. 
Although ACAP has been applied broadly in IS research, a paper by Roberts et al. (2012) is the only work which has reviewed and synthesized the role of ACAP in IS research by exploring ACAP at the theoretical level. However, the insights provided in Roberts et al. (2012) might be limited by its review of only nine top journals that included every article that uses ACAP, even if it is only a minor citation. In response to these issues, the aim of this paper is to conduct an extended literature analysis of the use of ACAP in IS research in order to create a solid foundation for advancing knowledge of this subject (Webster and Watson 2002).

The remainder of this paper is structured as follows. The next section presents the ACAP literature review. The third section describes the methodology used to conduct the review and the analysis of the application of ACAP in IS research. The fourth section provides the research findings. The fifth section highlights the important implications on the use of ACAP in future research, then follows the conclusions and contributions.

\section{Literature Review}

According to the seminal work of Cohen and Levinthal (1990), ACAP is a function of the firm's prior related and complementary knowledge. They emphasize that such capacity is pathdependent and critical to innovative performance, and they allude to the importance of "recognizing the value" of new external information by noting that this is difficult without prior knowledge. In terms of "assimilation," Cohen and Levinthal argue that the impact on the firm's ACAP by individual members is significant and critical to embedding new external information throughout the organization, and they cite research in the cognitive and behavioral sciences that underlie learning and knowledge-acquisition. This suggests that ACAP is dependent on the collective prior knowledge of individuals and that the firm's ACAP can be enhanced by investing in the ACAP of individuals and by advancing the R\&D, thus widening the potential interface between sources of external information and social networks within the firm. Consequently, the "assimilation" component of ACAP encompasses the firm's ability to Page 4 of 43 
transform, re-configure, and re-deploy resources in order to be ready to exploit new external information. Cohen and Levinthal also recognize that while the knowledge of individuals is important, ACAP "assimilation" is also dependent on the efficient proliferation and socialization of new external information in the firm, thus emphasizing that knowledge-retention into corporate memory is best facilitated by investing in, and encouraging, communication among the organization's sub-units. Cohen and Levinthal describe "applying new external information" as the exploitation of the newly acquired knowledge for commercial benefit to the organization based on technological opportunity, the volume of external knowledge available, and on the "regimes of appropriability" (innovation protection mechanisms that create a barrier between the organization and valuable external knowledge). They further argue that such exploitation of new external information is a critical component of a firm's innovative capabilities.

However, Zahra and George (2002) argue that ACAP should comprise two significant subcomponents: potential ACAP (PACAP), which is the dimensions of "acquisition" (new to ACAP) and "assimilation" (as per Cohen and Levinthal, 1990), and realized ACAP (RACAP), which is the commercial "exploitation" dimension (as per Cohen and Levinthal, 1990) and the "transformation" dimension (new to ACAP). With these two sub-set components, Zahra and George focus on an "efficiency view" of ACAP; that is, its efficiency in reducing the gap between an organization's PACAP and its RACAP. Put simply, a firm can, at best, only transform and exploit as much knowledge as it has acquired and assimilated, and an innovating firm should therefore aim to maximize the ratio of RACAP to PACAP. Lane, Koka, and Pathak (2006) also acknowledge the "efficiency view" proposed by Zahra and George (2002). However, they adopt a definition that rolls back the transformational component of the ACAP model proposed by Zahra and George (2002) to that proposed originally by Cohen and Levinthal (1990; 1994). Lane et al. (2006) justify this regression by suggesting that "transformation" is incorporated and assumed in the "assimilation" and "exploitation" components of their model. Todorova and Durisin (2007) further argue that there are serious ambiguities and omissions in 
Zahra and George's (2002) reconceptualization of ACAP and call into question the splitting of the construct into the sub-sets of PACAP and RACAP. Volberda, Foss, and Lyles (2010) propose an integrative framework for ACAP based largely on Zahra and George's (2002) model. However, their most important contribution is the emphasis on multilevel antecedents and contingent factors that influence the outcomes of organizational ACAP. Volberda et al. (2010) suggest that there is a need to consider "intra-organizational antecedents" and "managerial antecedents" as significant drivers of organizational ACAP.

Table 1 summarizes the commonalities and differences of the reviewed ACAP models. The cells highlighted in dark-grey indicate a commonality between all five major ACAP models. All of the models reviewed consider "assimilate" and "apply" as components of ACAP. Most of the models reviewed also consider "recognizing the value," "acquisition," and "transformation" as important components (light-grey highlighted cells). There appears to be agreement among these researchers regarding ACAP antecedents "knowledge source" and "prior knowledge", and with minimal agreement on other observed antecedent factors. There is less agreement, however, in regard to contingent factors although most agree that "regimes of appropriability" are a significant mediating factor. Cohen and Levinthal (1990) view "regimes of appropriability" as a mediating factor between ACAP antecedents and ACAP, taking the view that new external information as a source is limited by the intellectual-property protection mechanisms implemented by rival organizations to provide an effective barrier to knowledge transfer. Zahra and George (2002) suggest that "regimes of appropriability" mediate the relationship between ACAP and its outcomes, implying that the barrier lies not in the transfer of knowledge from an external source to the organization, but rather in the application and exploitation of that knowledge for achieving a desired outcome. Todorova and Durisin (2007) acknowledge both of these views. The majority of the models reviewed agree that "innovation," "performance," and "competitive advantage" are significant outcomes of ACAP. The models also tend to focus on 
the relationship of innovative performance as a driver of business performance (Cohen and Levinthal, 1990) and how ACAP can enhance the business performance of an organization.

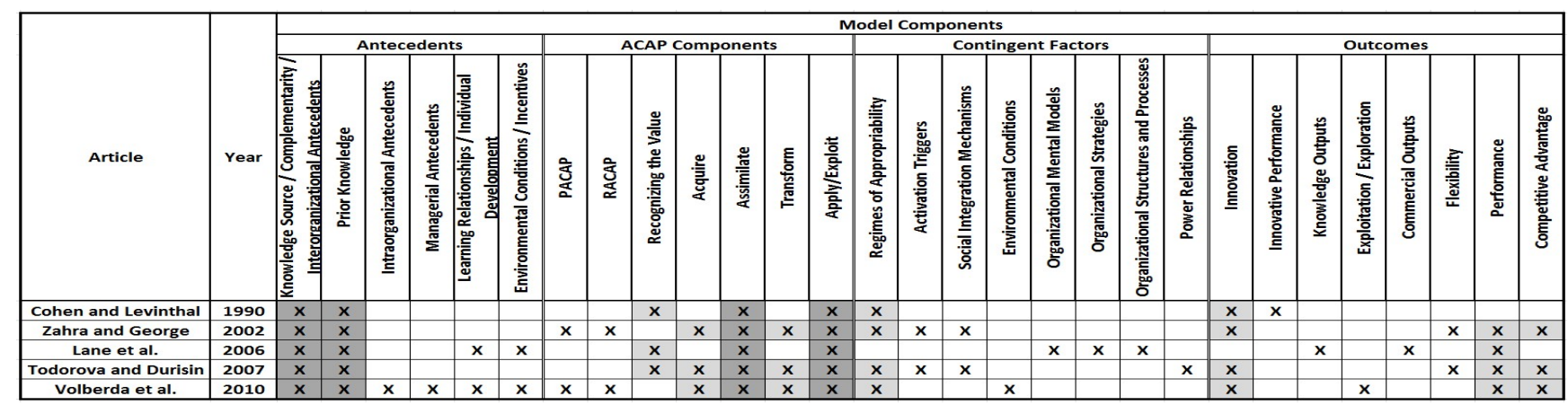

Table 1. Summary of the elements of the various ACAP models. (Note: dark-grey highlights show common views among all researchers in the sample; light-grey highlights a majority view.)

\section{Methodology}

The sample of papers has been specifically selected from peer-reviewed, academic journals that have been ranked by the Australian Council of Professors and Heads of Information Systems (ACPHIS). For reasons of credibility and manageability, the sample was limited to A* and A journals (i.e. the top two tiers) as they are regarded as highly reputable among IS researchers. The papers published in these journals are also likely to contain high-quality research, and thus making significant contributions to the body of knowledge. Another requirement for the selection of the papers was that any reference to ACAP must have, at the very least, assisted in the development of the logic for the paper's hypotheses/propositions and/or research models. Papers that only contained a minor or background reference to ACAP were not retained for review. The period of publication was specified as between 1990 and 2015.

The data collection was conducted using the search term "Absorptive Capacity" across all fields. This yielded $626 \mathrm{~A}^{*}$ and A papers, for which the PDFs were downloaded and the citations exported to the Endnote database. All papers were reviewed to determine which contained more 
than just a minor or background citation of seminal works on ACAP. This was done based on whether they used ACAP in a way that either (1) provided theoretical support (e.g., Overby et al. (2006)), (2) formed part of a hypothesis or proposition, or (3) formed the theoretical base of the research model and motivated the study (e.g., Arnold et al. (2010); Malhotra et al. (2005); Park et al. (2007)). Any papers that could not be categorized into these three groups were discarded because ACAP only featured as a background or minor citation in the studies. This brought the final number to 65 for review and analysis. A research matrix was created in accordance with the coding protocol developed (see AppendixA) to classify and summarize the papers reviewed, as suggested in Webster and Watson (2002). All analysis was conducted using Microsoft Excel and was cross-checked by the research team.

\section{Findings of ACAP Use in IS Research}

In the papers reviewed, the most common foundation theory was that of Cohen and Levinthal (1990) - 63 papers (97\%), followed by Zahra and George (2002) - 41 papers (63\%). Many papers cited both for various definitions and conceptual elements, but this was probably only an indicator of the age of both papers; it was not necessarily an indication of the quality of those works and nor did it infer a preference among the research community. About $91 \%$ of the papers were published between 2004 and 2015. Based on this sample, it appears that Zahra and George (2002) has stimulated much of the ACAP use in IS research in the last decade. Furthermore, the popularization of knowledge-management in the mid-2000s may have led to an increase in this area of research.

As for the unit of analysis (UoA), our sample shows that the majority adopts the organizational and group level of analysis (see Table 2 in Appendix B). This is in line with the argument that ACAP is generally regarded as an organizational-level construct (Lane et al., 2006; Todorova and Durisin, 2007; Zahra and George, 2002). It is also evident that, in the majority of papers (58\%), ACAP plays a significant role in forming the theoretical base. The UoA is also crosstabulated with the ACAP conceptualization of the papers (see Table 3). As shown in Table 3, the Page 8 of 43 
majority (94\%) conceptualize ACAP as a "capability" that is distinct from ACAP as an "asset." Boynton et al. (1994) is the only paper that describes research at the group (or sub-unit) level and distinctly conceptualizes ACAP as an "asset".

After this descriptive analysis of ACAP in IS research, the remaining of this results section is structured into (1) an analysis of technical and behavioral domains; (2) an analysis of the hypotheses and propositions (to demonstrate how ACAP is being used to explain various organizational phenomena in IS research), and (3) an analysis of the measurement instruments (to give insights into the operationalization of the ACAP in IS research).

\subsection{Analysis of domains}

We categorized the domain of study into technical and behavioral to understand where ACAP is being used in IS research. The "technical domain" refers to the IS area of interest, which can be a specific technology or group of technologies, such as Enterprise Resource Planning (ERP)/Enterprise Systems, or a specific academic research area or body of knowledge, such as knowledge management. The "behavioral domain" refers to some activities, manipulation, or application of the "technical domain." An example of such a domain is "utilization," which is a key area for research and one of the major challenges to the "adoption" and "assimilation" of enterprise systems in practice.

Table 4 shows that the most prevalent "technical domains" which use ACAP in IS research in the sample are as follows; 'Knowledge Management/Knowledge Management Systems (KMS)/Collaborative Technology'; 'ERP/Enterprise Systems/Platforms'; and 'IT Governance/Organization'. These technical domains are used in 44 articles (68\%). It was also observed that in conjunction with these technical domains, the behavioral domains of 'Knowledge Transfer/Sharing/Creation', 'Utilization', and ‘Adoption/Implementation/Integration' were used in 43 works (66\%). 
Nonetheless, it is pertinent to note that with increased spending on business intelligence (BI) and the associated technologies [e.g., data warehousing (DW), decision support systems (DSS), and customer relationship management (CRM)] in organizations, there are relatively few papers investigating the impact of ACAP in the DW/BI/DSS/CRM domain and, more importantly, the impact that this domain has on organizational ACAP. Gartner's worldwide surveys of information technology spending have shown that BI is one of the top technology priorities for many Chief Information Officers (CIOs) and predicts that BI and analytics will remain the top focus for CIOs until 2017 (Gartner Inc., 2016).

\subsection{Analysis of hypotheses and propositions}

From the analysis of the hypotheses and propositions described in the various papers on ACAP in IS it is possible to understand how the ACAP construct is being applied in IS research and how it is being used to explain certain organizational phenomena. Hypotheses and propositions are analyzed separately as they are different, and this will provide an in-depth insight for understanding this issue.

ACAP formed (part of) the basis of the hypothesis for the research models described in 43 of the articles (66\%). Of these, 21 papers (49\%) classified ACAP as an independent variable (IV), a dependent variable (DV), or a mediating variable (MED). In four papers (9\%), ACAP was a mediating factor. Fifteen articles (35\%) contained hypotheses where ACAP was a combination of IV, DV or MED. Only three papers (7\%) investigated the impact of IS on an organization's ACAP where ACAP is solely the DV in the research model. Furthermore, 11 papers included ACAP as propositions, but of these only four (36\%) used ACAP as IV while one (9\%) categorized ACAP as DV. Two articles (18\%) used ACAP as a mediating variable while the remaining four $(36 \%)$ used ACAP in combination. 


\section{Analysis of hypotheses}

In stage one, the collected hypotheses were analyzed at the individual-hypothesis level. In stage two, the hypotheses were then cross-tabulated with technical domains to highlight where ACAP is applied in IS research and to identify the level of support for the hypotheses. Each hypothesis was analyzed by (1) examining the research models of the papers, (2) determining how the hypothesis was derived, (3) ascertaining the dependent variables (DV), independent variables (IV), and any mediating variable (MED) being studied, (4) by locating ACAP in the hypothesis, and (5) by recording and tabulating the associated results from the study.

A total of 120 hypotheses relating to ACAP were extracted. All of them were tested by means of quantitative analysis. Table 5 shows that in 79 of the 120 hypotheses (66\%), ACAP is cast as the IV in the research model; that is, the researcher was interested in investigating the influence of ACAP on phenomena relating to IS. The data in Table 5 also show that among the hypotheses only $21 \%$ cast ACAP as the DV while two-thirds (66\%) represented it as an IV. This may indicate that, among the sample, researchers were more interested in studying the effects of ACAP on IS-related phenomena than examining the effects of IS on organizational ACAP. A small proportion of the hypotheses $(9 \%)$ cast ACAP as a mediating factor. This was evident in Pavlou and El Sawy (2006) who suggest that "IT leveraging competence" positively influences "dynamic capabilities (including ACAP)," which, in turn, positively influences "functional competencies." It was also evident in Francalanci and Morabito (2008) who suggest that "IS integration" positively influences ACAP which, in turn, positively influences "business performance." Moreover, it was noted that a small proportion of hypotheses (4\%) cast ACAP as both the IV and the DV. This was evident in the research models that attempted to operationalize aspects of the work of Zahra and George (2002) by analyzing the relationship between PACAP and RACAP. For example, Joshi et al. (2010) investigate the impact of IT on firm innovation and Park et al. (2007) examine how the components of ACAP interact by investigating the user's 
ability to "recognize the value" of information and how that would influence the usage or "assimilation" of ERP systems in a Korean context.

In stage two, three separate analyses of ACAP hypotheses, cross-tabulated with the technical domain of the associated paper, were conducted. Table 6 shows that the most prevalent domains identified are "IT Governance/Organization", "Knowledge Management/KMS/Collaborative Technology" and "ERP/Enterprise Systems/Platforms". It was notable that hypotheses relating to the "IT Governance/Organization" domain were more likely to cast ACAP as the DV, suggesting that the researchers were interested in investigating the effect of IS phenomena (IV) on organizational ACAP (DV).

Closer inspection of the hypotheses reveals that while the research projects were published in respected IS journals, the IVs in these instances were not core IS issues. Instead, they were predominantly organizational or environmental factors including, but not limited to, "change disposition" or "hostility in external environment." These variables do not specifically represent a significant IS technology or body of knowledge. Rather, they are organizational factors that may interact with some aspects of an IS. Similar patterns can be observed in the supported hypotheses and their associated technical domains. When considering non-supported hypotheses and their associated technical domains it is interesting to note that the most prevalent domain in the sample is "ERP/Enterprise Systems/Platforms" and "B2B/E-commerce/Internet". Further analysis incorporating the behavioral domain of the papers was conducted to illustrate the types of activities that involve ACAP within the supported hypotheses (see Table 7). Among the supported hypotheses, the most prevalent behaviors are 'Utilization' (25\%) and 'Knowledge Transfer/Sharing/Creation' (25\%), with ACAP cast predominantly as the IV in both cases. The casting of ACAP as the DV is also most prevalent in "Utilization" behaviors, and "Knowledge Transfer/Sharing/Creation'. 


\section{Analysis of propositions}

The proposition analysis follows an approach similar to the hypothesis analysis. From the 11 papers reviewed, a total of 46 propositions relating to ACAP were identified. All the propositions are supported. Unlike the hypothesis analysis, the proposition analysis (see Table 8) showed a strong preference to represent ACAP as DV (24 of 46 propositions - 52\%) instead of IV (nine propositions $-20 \%$ ). Most propositions are strongly supported based on qualitative data analysis methods (80\%) and 19 propositions (79\%) were cast as DV used qualitative analysis (see Table 9). A closer inspection reveals that they are strongly related to knowledge in which 'knowledge' was used as a construct in most of the propositions. As knowledge is a variable that is difficult to quantify, qualitative analysis can provide better insights and is easier to justify.

Table 10 shows a pattern similar to that seen previously with the domain-analysis of ACAP in IS research at the paper level. That is, the most prevalent domains identified among ACAP-related propositions were from articles classified as 'Knowledge Management/KMS/Collaborative Technology', and also 'ERP/Enterprise Systems/Platforms' domains respectively. However, there were no papers which were classified under 'IT Governance/Organization'.

Based on the findings, the propositions are mainly represented as DV in which 14 DV propositions belong to 'Knowledge Management/KMS/Collaborative Technology' while six were on 'ERP/Enterprise Systems/Platforms'. Further analysis incorporating the behavioral domain of papers was conducted to illustrate the kinds of activity involving ACAP within the proposition studied (see Table 11). 'Knowledge Transfer/Sharing/Creation' can be seen as the dominant behavioral area accounting for $57 \%$ followed by 'innovation/organizational performance' which accounts for $24 \%$ of the propositions. Unlike the hypotheses, in these areas ACAP are predominantly cast as DV. Since the behavioral and technical domains focus on knowledge, it is probable that the aim of their respective research projects was towards knowledge-creation and sharing, thus an antecedent of ACAP, which leads to casting ACAP as a DV in both cases. 


\subsection{Analysis of measures}

By analyzing the measurement instruments used in the research papers it is possible to gain an understanding of how ACAP is measured in practice and to evaluate the consistency between its conceptualization and operationalization. Thirty-eight $(59 \%)$ of the sample papers contained some form of instrument, such as survey or interview questions, to measure ACAP, and nearly one-third of those cite Szulanski (1996) as the source of the instrument (solely or in conjunction with other sources). Xu and Ma (2008), for example, use Szulanski (1996) to measure the knowledge transferred in ERP implementation, giving the impression that ACAP is a knowledge asset.

Two hundred and sixty three measurement instruments were located and recorded. Table 12 summarizes the sources of the ACAP instruments, these being cross-tabulated with the aspects of interest for the instruments. Ninety-three $(35 \%)$ of the measurement instruments had multiple sources with 39 being derived from Cohen and Levinthal (1990). Of these 39, 15 were obtained in conjunction with other sources outside of this review, and 23 were sourced in conjunction with Boynton et al. (1994). Only one measurement used sources from Cohen and Levinthal (1990) and Zahra and George (2002).

Forty-four (17\%) of the instruments were sourced solely from Szulanski (1996), but this proportion is increased to $19.77 \%$ when the instruments from multiple sources, including Szulanski (1996), are considered. Table 12 also illustrates that nearly 42\% of the instruments are "indirect." That is, instead of alluding to the measurement of one of the previously recognized components of ACAP (such as "recognizing the value," and "assimilation"), these instruments refer to the measurement of antecedents (predictors) or outcomes of ACAP. This could explain the small proportion of hypotheses that cast ACAP as the DV in the research models that were reviewed. 
Table 13 shows the implied conceptualization of the measurement instruments in relation to the aspect of ACAP they are intended to measure. The "capability" conceptualization of ACAP appears to be the dominant instrument structure (188 or $71 \%$ ) among the measurement instruments, and this indicates that the operationalization of ACAP with regard to those instruments is generally viewed "as intended" by most researchers. Interestingly, among the indirect aspects of ACAP, $85 \%$ of the conceptualizations of measurement instruments were "asset"-based (45 "antecedent" and 17 "outcome" from a total of 73). This is in contrast to "capability"-based conceptualizations which are most prevalent among "components" of ACAP (141 out of $188-75 \%)$.

With such high levels of antecedent being conceptualized as an asset the question arises as to whether IS research has been applying appropriate and correct forms of measurement. A further analysis was conducted to understand this matter, as shown in Table 14. Szulanski's (1996) paper has shown a strong influence on conceptualizing ACAP as an asset at a measurement level (26 measurements) followed by multiple-source authors (15 measures) and unspecified or unclear sources (10 measures). This confirms the importance of understanding the key concepts of ACAP and ensuring that the measurements applied are in accordance with the paper's conceptualization.

Based on Table 15, which analyzes the measurements that categorized ACAP as an asset, Szulanski's paper has shown a strong influence on measuring the antecedent factors as an asset (21 measures). Szulanski's measurements accounted for $36 \%$ of the total number of measurements that classified ACAP as an asset. This is closely followed by the multiple-sourced articles that represent $21 \%$ of the total asset classification in which 12 measures were antecedent factors and three were ACAP component measures.

In addition to Cohen and Levinthal (1990), it can be seen that Szulanski's (1996) work has had a strong influence on the approaches to measuring ACAP. Indeed, his research instrument has Page 15 of 43 
been adopted widely in subsequent studies and his ACAP measurement has had a far-reaching influence on other related studies. This is probably because Szulanski's (1996) paper is one of the earliest ACAP papers that provided a comprehensive survey instrument. In other words, that publication's timing and the provision of a readily-adaptable measurement led to Szulanski's (1996) work having greater influence than other ACAP papers published later in 2000s.

Szulanski's (1996) work (see Table 16) aligned with that of Cohen and Levinthal (1990), thus classifying ACAP as a capability. However, among the different antecedent factors of ACAP, Szulanski's paper categorized most of the prior knowledge factor as an asset instead of a capability. According to Cohen and Levinthal (1990, p128), prior knowledge "includes basic skills or even a shared language but may also include knowledge of the most recent scientific or technological developments in a given field". What an organization can do is highly dependent on what it has done and learned before (Kogut and Zander, 1992; McDonald and Madhavaram, 2007) which implies that prior knowledge itself is a process. This is because the experiences and knowledge that are accumulated by an organization are considered an organizational-learning process. In order for prior knowledge to be an antecedent factor of ACAP it has to be able to "confer an ability to recognize the value of new information, assimilate it, and apply it to commercial ends" (Cohen and Levinthal, 1990, p128). The word 'ability' shifts the conceptualization of prior knowledge from an asset to a capability perspective, as this becomes a process instead of a static form of resource.

Thus, as various authors have adopted Szulanski's measurements in IS research, this increases the number of measures that conceptualized ACAP as an asset. This is especially so when measuring the antecedents as most authors used Szulanski's measures on prior knowledge. Hence, although many papers conceptualize ACAP correctly at a paper level, operationalizing ACAP at a measurement level has shown some inconsistency which indicates some misconceptualization at a measurement level. 


\section{Discussions and Implications}

Overall, the study revealed that the most prevalent technical domains associated with the use of ACAP in IS research were "Knowledge Management/KMS/Collaborative Technology" and "ERP/Enterprise Systems/Platforms" while the most prevailing behavioral domains were "Knowledge Transfer/Sharing/Creation," "Utilization" (of IS), and "Adoption/Implementation/Integration." Given that ACAP is closely related to knowledge management and organizational learning, this was to be expected. More importantly, the analysis has shown that researchers in the IS field concur that ACAP should be conceptualized as an organizational "capability" rather than as an "asset." The "capability" conceptualization takes into account the path dependency aspect of "prior knowledge" (Cohen and Levinthal, 1990) as well as the component processes required to generate exploitable knowledge in the organization. Conversely, the "asset" conceptualization of ACAP does not consider the "identification," "assimilation," "transformation," and "application" of valuable new knowledge.

The "capability" conceptualization is related to the gain and release of resources in terms of routines. Examples include knowledge-creation routines in which individuals build new thinking within an organization, and alliances of acquisition routines that bring new resources into the firm from external sources (Eisenhardt and Martin, 2000). Hence, ACAP is a process or organizational routine that follows closely the characteristics of a capability. On the other hand, 'asset' is a stock of relevant prior knowledge and thus it is a knowledge-base of a firm which implies a static form of asset instead of a process (Lane et al., 2006). Hence, unlike the capability conceptualization, asset conceptualization does not accurately capture the characteristics of ACAP. Therefore, ACAP should be conceptualized as a "capability" and not an "asset", which implies that there is a further research opportunity to refine or perhaps specialize ACAP; for example, by the use of knowledge integration and reconfiguration, and by examining the role of IT artifacts in facilitating and accelerating this capability conceptualization. 
In addition, the findings revealed that the majority of existing studies use indirect measurement of ACAP either to measure the antecedents such as "prior knowledge" or "inter-organizational factors", or to measure the outcomes such as "competitive advantage" and "innovation." Few directly measure the component of ACAP such as "recognizing the value" or "assimilation." As revealed in the literature analysis, the use of indirect measurements may lead to a mismatch in conceptualization and operationalization as it captures only the asset facet of the ACAP. Furthermore, we found that Szulanski's (1996) paper is the most commonly-used measurements for analyzing ACAP. However, half of the items in Szulanski (1996) measure asset rather than capability. Since misconceptualization and operationalization can lead to validity issues, we suggest future research to exercise care in aligning ACAP conceptualization and operationalization. While the components of ACAP can be challenging to measure, more effort should be focused on measuring ACAP characteristics. Also, Szulanski's (1996) measurement items could be modified (see Table 17) to include words such as 'ability', 'process' and 'capability' to imply “capability” conceptualization. In this research, we have also provided a compiled list of the measurements according to the areas of ACAP (see Table 18).

Furthermore, the ACAP construct is based on an organizational level of analysis and so the application of this construct on an individual level can lead to misconceptualization. However, it cannot be ignored that ACAP is dependent on the level of individual inputs, as explained by Cohen and Levinthal (1990). Knowledge at an individual level will not have a strong impact on an organization unless it has been encapsulated at the organizational level. One of the focuses of ACAP is the ability to apply and exploit the knowledge which benefits the organization in terms of innovation, competitive advantage, or organizational performance. Thus, an individual's knowledge will remain private or has no impact on an organization unless it has been captured at an organizational level. Although researchers have tried to justify the applicability of ACAP at an individual level, this construct should be conceptualized at an organizational level. It is suggested that, in studying knowledge at an individual level, researchers can use the 
organizational knowledge-creation theory as it is applicable to all different levels of analysis. This makes it flexible, thus reducing the probability of misconceptualization.

In the literature, ACAP has been classified as IV, DV, or as a mediating construct. It was found that approximately 19 articles (44\%) containing hypotheses and six articles (55\%) containing propositions have classified ACAP as either IV and DV, or as MED. Research that analyzed ACAP as both IV and DV, or as MED, has produced more comprehensive papers because they analyzed ACAP thoroughly. ACAP has been defined as "prior related knowledge [which] confers an ability to recognize the value of new information, assimilate it, and apply it to commercial ends" (Cohen and Levinthal, 1990, p128), and this implies that there are antecedent factors and outcomes in ACAP - thus confirming that the construct is in the middle of two variables. When examining ACAP, antecedent factors such as prior related knowledge affect ACAP, thus classifying ACAP as the DV. Outcomes such as the application of knowledge to commercial ends should also be examined as an output of ACAP, thus classifying ACAP as an IV. Therefore, in order to fully examine ACAP, these two factors should be included in the analysis by having multiple hypotheses or propositions which cast ACAP as IV and DV, or as MED.

A further finding observed in this research is that only a few papers investigated the impact of IS on organizational ACAP (only $29.23 \%$ examined this phenomenon). Instead, this paper reveals a strong preference $(70.77 \%)$ among researchers for highlighting the impact of ACAP on ISrelated organizational phenomena; for example, on the level of knowledge transferred in an ERP implementation (Liu et al., 2011). In the current climate, there would be significant interest in an investigation of the extent to which IS influences organizational ACAP and how that, in turn, influences the "competitive advantage" of the organization.

In summary, various misalignments between ACAP conceptualization, operationalization and measurement, and the level of analysis in the literature does a disservice to the accumulated Page 19 of 43 
research in ACAP. While it may be argued that ACAP is relatively 'young' compared with many other concepts, the period since the formative conceptual work by Cohen and Levinthal (1990) should have allowed time for researchers to resolve any misalignments. More importantly, extra care should be exercised when applying and relating concepts from other disciplines to the discipline of IS. In future, it is essential that researchers ensure that all three components of ACAP - conceptualization, operationalization and measurement, as well as the level of analysis are fully aligned so that a correct and valuable stream of IS-based work can contribute to the body of knowledge on ACAP. As such we see the need for normative guidelines on the use of ACAP, especially for use by disciplines (such as IS research) that draw on ACAP as construct to ensure researchers are indeed aligning its conceptualization, operationalization and measurement, and the level of analysis.

\section{Conclusions and Contributions}

This paper has reviewed and analyzed the use of the ACAP construct in IS research since its seminal inception. Based on an in-depth literature analysis of ACAP-related papers published in 53 reputable IS journals from 1990 to 2015, this paper highlighted several interesting phenomena for ACAP use and revealed that ACAP is a significant and well-received concept in IS research. It showed that while there is a broad range of applications for ACAP in IS research, it is predominantly used to explain IS adoption, implementation, or usage behaviors, specifically within the knowledge-management and enterprise-systems technical domains. It also showed that the majority of the research correctly conceptualizes ACAP as a capability. However, various misalignments between ACAP conceptualization, operationalization and measurement, and the level of analysis remain a concerning issue requiring immediate attention from researchers. Interestingly, this study also uncovers that Szulanski's (1996) work had a substantial influence (in terms of citations and adoption of research measurements) in subsequent ACAP studies because it was the earliest work that provided a complete research instrument. 
This research makes several contributions to the body of knowledge. First, this research has provided an in-depth literature analysis of ACAP usage in IS research papers sourced from topranked academic journals from the inception of ACAP in 1990 through to 2015. Notably, the synthesis provided here complements the work of Roberts et al.'s (2012) and adds to the body of knowledge of ACAP in IS research. These are achieved by empirically examining the applications of ACAP and associated factors in IS research in order to show the extent to which the construct has been applied to explain various organizational phenomena. This paper thus further extends the work of Roberts et al. (2012). While Roberts et al. target a smaller group of journals (nine top journals), this paper includes all $\mathrm{A}^{*}$ and A journals (53 journals) listed by the Australian Council of Professors and Heads of Information Systems (ACPHIS), thus providing a more comprehensive view of the articles that use ACAP. Furthermore, this paper examines only those articles that use ACAP in their core development, while Roberts et al. (2012) included every article that uses ACAP, even if it is only a minor citation. Besides the analyses of the role of ACAP in IS research, the units of analysis where ACAP is being applied, and the operationalization and measures of ACAP; the cross-tabulation analyses presented in this paper give a more comprehensive synthesis of the application of ACAP than was provided by Roberts et al. (2012). Additionally, this paper presents an analysis of how ACAP is being represented in the articles as either a dependent or an independent variable or as a mediator, an analysis which is absent in Roberts et al. (2012).

Besides that, this research has provided a method for analyzing and presenting the application of ACAP constructs to IS research by collecting and synthesizing research-model hypotheses and propositions. It also considers the measurement instrument data for both quantitative and qualitative analyses. In other words, this paper makes an important contribution in terms of the methodology used to conduct a literature analysis in order to contrast and combine elements of different studies utilizing the same construct. In addition, this paper also provides a tabular synthesis of ACAP model components in order to achieve a better analysis of the ACAP 
construct and its evolution. This tabular approach or analysis structure could be applied to research areas in other disciplines.

In terms of research limitation, this paper focused on the IS domain and gathered data only from reputable journals ranked in the top two tiers of ACPHIS list. Future research could include additional IS journals especially the relatively new journals and non-ACPHIS journal list such as the Association of Business Schools (ABS) list. Nevertheless, this paper scrutinizes the existing usage of ACAP in IS research and aids future researchers to correctly apply ACAP. 


\section{References}

Armstrong, C. P., and Sambamurthy, V. (1999). Information technology assimilation in firms: The influence of senior leadership and IT infrastructures. Information Systems Research, 10(4), 304-327.

Arnold, V., Benford, T., Hampton, C., and Sutton, S. G. (2010). Competing pressures of risk and absorptive capacity potential on commitment and information sharing in global supply chains. European Journal of Information Systems, 19(2), 134-152.

Bharati, P., Zhang, C., and Chaudhury, A. (2014). Social media assimilation in firms: Investigating the roles of absorptive capacity and institutional pressures. Information Systems Frontiers, 16(2), 257-272.

Boynton, A. C., Zmud, R. W., and Jacobs, G. C. (1994). The influence of IT management practice on IT use in large organizations. MIS Quarterly, 18(3), 299-318.

Chengalur-Smith, I., Nevo, S., and Demertzoglou, P. (2010). An empirical analysis of the business value of open source infrastructure technologies. Journal of the Association for Information Systems, 11(11), 708-729.

Chou, S. W., Techatassanasoontorn, A. A., and Hung, I. H. (2015). Understanding commitment in business process outsourcing relationships. Information \& Management, 52(1), 30-43.

Cohen, W. M., and Levinthal, D. A. (1990). Absorptive capacity: A new perspective on learning and innovation. Administrative Science Quarterly, 35(1), 128-152.

Cohen, W. M., and Levinthal, D. A. (1994). Fortune favors the prepared firm. Management Science, 40(2), 227-251.

Díaz-Díaz, N. L., and De Saá-Pérez, P. (2014). The interaction between external and internal knowledge sources: An open innovation view. Journal of Knowledge Management, $18(2), 430-446$.

Eisenhardt, K. M., and Martin, J. A. (2000). Dynamic capabilities: What are they? Strategic Management Journal, 21(10-11), 1105-1121. 
Francalanci, C., and Morabito, V. (2008). IS integration and business performance: The mediation effect of organizational absorptive capacity in SMEs. Journal of Information Technology, 23(4), 297-312.

Gartner Inc. (2016). Gartner predicts business intelligence and analytics will remain top focus for CIOs through 2017. Gartner Newsroom. Retrieved 26th of August, 2016, from http://www.gartner.com/newsroom/id/2637615

Harrington, S. J., and Guimaraes, T. (2005). Corporate culture, absorptive capacity and IT success. Information and Organization, 15(1), 39-63.

Jansen, J. J. P., Van Den Bosch, F. A. J., and Volberda, H. W. (2005). Managing potential and realized absorptive capacity: How do organizational antecedents matter? Academy of Management Journal, 48(6), 999-1015.

Jiménez-Castillo, D., and Sánchez-Pérez, M. (2013). Nurturing employee market knowledge absorptive capacity through unified internal communication and integrated information technology. Information \& Management, 50(2-3), 76-86.

Joshi, K. D., Chi, L., Datta, A., and Han, S. (2010). Changing the competitive landscape: Continuous innovation through IT-enabled knowledge capabilities. Information Systems Research, 21(3), 472-495.

Ko, D.-G., Kirsch, L. J., and King, W. R. (2005). Antecedents of knowledge transfer from consultants to clients in enterprise system implementations. MIS Quarterly, 29(1), 59-85.

Kogut, B., and Zander, U. (1992). Knowledge of the firm, combinative capabilities, and the replication of technology. Organization Science, 3(3), 383-397.

Lane, P. J., Koka, B. R., and Pathak, S. (2006). The reification of absorptive capacity: A critical review and rejuvenation of the construct. Academy of Management Review, 31(4), 833863.

Liang, H., Saraf, N., Hu, Q., and Xue, Y. (2007). Assimilation of enterprise systems: The effect of institutional pressures and the mediating role of top management. MIS Quarterly, $31(1), 59-87$. 
Lin, T.-C., Ku, Y.-C., and Huang, Y.-S. (2014). Exploring top managers' innovative IT (IIT) championing behavior: Integrating the personal and technical contexts. Information \& Management, 51(1), 1-12.

Liu, L., Feng, Y., Hu, Q., and Huang, X. (2011). From transactional user to VIP: How organizational and cognitive factors affect ERP assimilation at individual level. European Journal of Information Systems, 20(2), 186-200.

Malhotra, A., Gosain, S., and El Sawy, O. A. (2005). Absorptive capacity configurations in supply chains: Gearing for partner-enabled market knowledge creation. MIS Quarterly, 29(1), 145-187.

Martelo-Landroguez, S., and Cegarra-Navarro, J.-G. (2014). Linking knowledge corridors to customer value through knowledge processes. Journal of Knowledge Management, 18(2), 342-365.

Martín-de Castro, G., López-Sáez, P., and Delgado-Verde, M. (2011). Towards a knowledgebased view of firm innovation: Theory and empirical research. Journal of Knowledge Management, 15(6), 871-874.

McDonald, R. E., and Madhavaram, S. (2007). What firms learn depends on what firms know: The implications of prior knowledge for market orientation. Marketing Management Journal, 17(1), 171-183.

Mishra, A. N., Konana, P., and Barua, A. (2007). Antecedents and consequences of Internet use in procurement: An empirical investigation of U.S. manufacturing firms. Information Systems Research, 18(1), 103-120.

Overby, E., Bharadwaj, A., and Sambamurthy, V. (2006). Enterprise agility and the enabling role of information technology. European Journal of Information Systems, 15(2), 120-131.

Park, J.-H., Suh, H.-J., and Yang, H.-D. (2007). Perceived absorptive capacity of individual users in performance of enterprise resource planning (ERP) usage: The case for Korean firms. Information \& Management, 44(3), 300-312. 
Pavlou, P. A., and El Sawy, O. A. (2006). From IT leveraging competence to competitive advantage in turbulent environments: The case of new product development. Information Systems Research, 17(3), 198-227.

Riemenschneider, C. K., Allen, M. W., Armstrong, D. J., and Reid, M. F. (2010). Potential absorptive capacity of state IT departments: A comparison of perceptions of CIOs and IT managers. Journal of Organizational Computing and Electronic Commerce, 20(1), 6890.

Roberts, N., Galluch, P. S., Dinger, M., and Grover, V. (2012). Absorptive capacity and information systems research: Review, synthesis, and directions for future research. MIS Quarterly, 36(2), 625-648.

Saraf, N., Langdon, C. S., and El Sawy, O. (2013). IS integration and knowledge sharing in multi-unit firms: The winner's curse. European Journal of Information Systems, 22(6), 592-603.

Saraf, N., Liang, H., Xue, Y., and Hu, Q. (2013). How does organizational absorptive capacity matter in the assimilation of enterprise information systems? Information Systems Journal, 23(3), 245-267.

Szulanski, G. (1996). Exploring internal stickiness: Impediments to the transfer of best practice within the firm. Strategic Management Journal, 17 (Winter Special Issue), 27-43.

Tiwana, A., and McLean, E. R. (2005). Expertise integration and creativity in information systems development. Journal of Management Information Systems, 22(1), 13-43.

Todorova, G., and Durisin, B. (2007). Absorptive capacity: Valuing a reconceptualization. Academy of Management Review, 32(3), 774-786.

Tsou, H.-T., and Chen, J.-S. (2012). The influence of interfirm codevelopment competency on eservice innovation. Information \& Management, 49(3-4), 177-189.

Volberda, H. W., Foss, N. J., and Lyles, M. A. (2010). Absorbing the concept of absorptive capacity: How to realize its potential in the organization field. Organization Science, 21(4), 931-951. 
Webster, J., and Watson, R. T. (2002). Analyzing the past to prepare for the future: Writing a literature review. MIS Quarterly, 26(2), 13-23.

$\mathrm{Xu}$, Q., and Ma, Q. (2008). Determinants of ERP implementation knowledge transfer. Information \& Management, 45(8), 528-539.

Zahra, S. A., and George, G. (2002). Absorptive capacity: A review, reconceptualization, and extension. Academy of Management Review, 27(2), 185-203. 


\section{Appendix A: Coding Protocol}

\section{Journal Article}

J1. Author's Name

J2. Title of the Article

\section{General Information of Article}

G1. When was the article published?

1. $1990-2003$

2. 2004-2015

G2. What is the ACPHIS ranking of the article?

1. $\mathrm{A}^{*}$

2. A

3. Others

G3.What is the research method of the article?

1. Conceptual Study

2. Field Study

3. Literature Review

4. Design Science

5. Case Study

6. Experimental

7. Survey

8. Action Research

G4. What was the data collection method?

1. Interview

2. Survey

3. Multiple

4. Literature

5. Others

G5. What was the data analysis method used?

1. Qualitative Analysis

2. Quantitative Analysis

3. Both

G6.What is the role of ACAP in the article?

1. Forms theoretical base for the article

2. Used in hypothesis, proposition or research model

3. Provides theoretical support 
G7. Which author was the ACAP definition based on?

1. Cohen \& Levinthal (1990)

2. Zahra \& George (2002)

3. Lane et al. (2006)

4. Todorova \& Durisin (2007)

5. Volberda et al. (2010)

G8. Which author was the foundation of ACAP concept based on?

1. Cohen \& Levinthal (1990)

2. Zahra \& George (2002)

3. Lane et al. (2006)

4. Todorova \& Durisin (2007)

5. Volberda et al. (2010)

6. Szulanski (1996)

G9. What was the Technical Domain of the article?

1. Knowledge Management / KMS / Collaborative Technology

2. ERP / Enterprise System / Platforms

3. Software Development

4. IT Governance / Organization

5. $\mathrm{DW} / \mathrm{BI} / \mathrm{DSS} / \mathrm{CRM}$

6. B2B / E-Commerce / Internet

7. Other

G10. What was the behavioral domain of the article?

1. Knowledge Transfer / Sharing / Creation

2. Utilization

3. Adoption / Implementation / Integration

4. Innovation

5. Offshoring / Outsourcing

6. Other

G11. What is the unit of analysis?

1. Individual

2. Organization

3. Group

4. Others

G12. What is the implied conceptualization of the measurement instrument collected?

1. Capability

2. Asset

3. Unclear 


\section{Hypothesis / Proposition}

H1. Does the article use hypothesis or propositions?

1. Hypothesis

2. Proposition

3. None

*Note: If hypothesis/proposition, proceed to excel sheet to provide further details of each hypothesis/proposition.

Hs1. Does the article use a hypothesis or proposition?

1. Hypothesis

2. Proposition

Hs2. List the hypothesis / proposition statement;

Hs3. What is the independent variable?

Hs4. What is the dependent variable?

Hs5. What is the outcome of the statement?

Hs6. Is the ACAP classified as an IV/DV?

1. Independent Variable

2. Dependent Variable

\section{Measurements}

M1. Are the measurements of the data explicitly stated in the article?

1. Yes

2. No

*Note: If yes, proceed to excel sheet to provide further details of the measurements.

Ms1. List the measurement questions

Ms2. Who is the measurement source (author)?

Ms3. What is the question attempting to explain?

1. Component

2. Outcome

3. Antecedent

4. Contingent Factor

Ms4. Which aspect of ACAP is the question measuring?

Ms5. What is the measurement's implied conceptualization?

1. Asset

2. Capability 
Appendix B: ACAP Measurement (Due to the large number of tables, most tables are provided in Appendix B here to avoid disengagement in the above text)

Table 2. Analysis of UoA and Role of ACAP in IS Research

\begin{tabular}{|l|c|c|c|c|c|}
\hline \multicolumn{1}{|c|}{ Count of Papers } & \multicolumn{4}{|c|}{ Role of ACAP in Article } \\
\hline Unit of Analysis & $\begin{array}{c}\text { Forms theoretical } \\
\text { base for the article }\end{array}$ & $\begin{array}{c}\text { Provides } \\
\text { theoretical } \\
\text { support }\end{array}$ & $\begin{array}{c}\text { Used in hypothesis, } \\
\text { proposition or research } \\
\text { model }\end{array}$ & Total & $\%$ \\
\hline Organization & 19 & 3 & 10 & 32 & $49 \%$ \\
\hline $\begin{array}{l}\text { Multi (Group \& } \\
\text { Organization) }\end{array}$ & 9 & 1 & 1 & 11 & $17 \%$ \\
\hline $\begin{array}{l}\text { Multi (Individual \& } \\
\text { Group) }\end{array}$ & 5 & 1 & 2 & 8 & $12 \%$ \\
\hline $\begin{array}{l}\text { Multi (Individual \& } \\
\text { Organization) }\end{array}$ & 2 & 1 & 1 & 4 & $6 \%$ \\
\hline $\begin{array}{l}\text { Multi (Individual \& } \\
\text { Group \& Organization) }\end{array}$ & 3 & 1 & & 1 & $2 \%$ \\
\hline Individual & & 1 & 1 & 7 & $11 \%$ \\
\hline Group & $\mathbf{3 8}$ & $\mathbf{8}$ & $\mathbf{1 9}$ & 2 & $3 \%$ \\
\hline Grand Total & $\mathbf{5 8}$ & $\mathbf{1 2 \%}$ & $\mathbf{2 9} \%$ & $\mathbf{6 5}$ & $\mathbf{1 0 0 \%}$ \\
\hline Percentage & & & & & \\
\hline
\end{tabular}

Table 3. Cross-Tabulation of ACAP Conceptualization with Unit of Analysis (UoA)

\begin{tabular}{|c|c|c|c|c|c|c|c|c|c|}
\hline Count of Papers & \multicolumn{7}{|c|}{ Unit of Analysis } & \multirow[b]{2}{*}{ Total } & $\%$ \\
\hline $\begin{array}{c}\text { ACAP } \\
\text { Conceptualization }\end{array}$ & 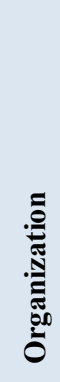 & 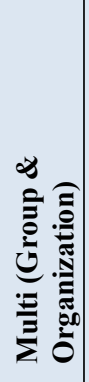 & 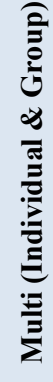 & 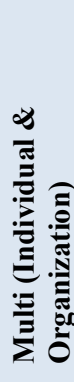 & 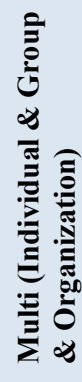 & 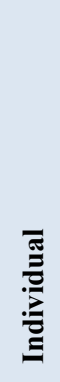 & ق̃ & & \\
\hline Capability & 31 & 10 & 7 & 4 & 1 & 7 & 1 & 61 & $94 \%$ \\
\hline Asset, Capability & 1 & 1 & 1 & & & & & 3 & $5 \%$ \\
\hline Asset & & & & & & & 1 & 1 & $2 \%$ \\
\hline Grand Total & 32 & 11 & 8 & 4 & 1 & 7 & 2 & 65 & $\begin{array}{c}100 \\
\%\end{array}$ \\
\hline Percentage & $\begin{array}{l}49 \\
\%\end{array}$ & $\begin{array}{l}17 \\
\%\end{array}$ & $\begin{array}{l}12 \\
\%\end{array}$ & $6 \%$ & $2 \%$ & $\begin{array}{l}11 \\
\%\end{array}$ & $\begin{array}{c}3 \\
\%\end{array}$ & & \\
\hline
\end{tabular}


Table 4. Cross-Tabulation of Technical and Behavioral Domains

\begin{tabular}{|c|c|c|c|c|c|c|c|c|c|}
\hline Count of Papers & & & & inical Dc & & & & & \\
\hline Behavioral Domain & 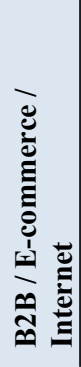 & 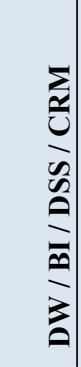 & 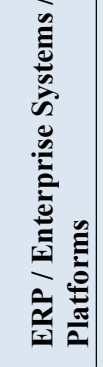 & 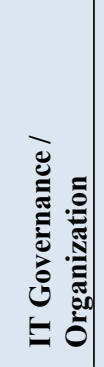 & 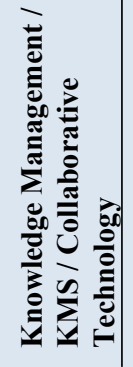 & 离 & 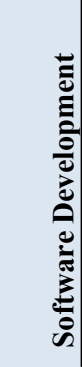 & $\stackrel{\bar{\sigma}}{\stackrel{\sigma}{*}}$ & : \\
\hline $\begin{array}{l}\text { Knowledge Transfer / Sharing / } \\
\text { Creation }\end{array}$ & 1 & & 3 & 2 & 10 & 1 & 1 & 18 & $28 \%$ \\
\hline Utilization & 3 & 1 & 3 & 4 & & & 2 & 13 & $20 \%$ \\
\hline Adoption / Implementation / Integration & 1 & 1 & 6 & 3 & & 1 & & 12 & $18 \%$ \\
\hline $\begin{array}{l}\text { Innovation / Organizational } \\
\text { Performance }\end{array}$ & & & 1 & 3 & 6 & & 1 & 11 & $17 \%$ \\
\hline Other & 1 & 1 & & 1 & 1 & 4 & & 8 & $12 \%$ \\
\hline Offshoring / Outsourcing & & 1 & & & 1 & & 1 & 3 & $5 \%$ \\
\hline Total & 6 & 4 & 13 & 13 & 18 & 6 & 5 & 65 & \\
\hline Percentage & $9 \%$ & $6 \%$ & $20 \%$ & $20 \%$ & $28 \%$ & $9 \%$ & $8 \%$ & $100 \%$ & \\
\hline
\end{tabular}

Table 5. Summary of Hypotheses Collected from ACAP in IS Research Papers

\begin{tabular}{|l|c|c|c|c|}
\hline \multicolumn{1}{|c|}{$\begin{array}{c}\text { Count of Hypotheses } \\
\text { ACAP cast as }\end{array}$} & Supported & No Evidence of Support & Total & \% \\
\hline IV & 63 & 16 & 79 & $66 \%$ \\
\hline DV & 22 & 3 & 25 & $21 \%$ \\
\hline IV \& DV & 5 & 0 & 5 & $4 \%$ \\
\hline MED & 9 & 2 & 11 & $9 \%$ \\
\hline Total & $\mathbf{9 9}$ & $\mathbf{2 1}$ & $\mathbf{1 2 0}$ & $\mathbf{1 0 0 \%}$ \\
\hline Percentage & $\mathbf{8 2 . 5 \%}$ & $\mathbf{1 7 . 5 \%}$ & $\mathbf{1 0 0 \%}$ & \\
\hline
\end{tabular}


Table 6. Analysis of Hypotheses Collected from ACAP in IS Research Papers Cross-Tabulated with the Technical Domain of the Source Paper for the Respective Hypotheses

\begin{tabular}{|c|c|c|c|c|c|c|c|c|c|c|c|c|c|c|}
\hline \multirow{3}{*}{$\begin{array}{l}\begin{array}{c}\text { Count of } \\
\text { Hypotheses }\end{array} \\
\\
\text { Technical } \\
\text { Domain }\end{array}$} & \multicolumn{11}{|c|}{ ACAP is cast as } & & & \\
\hline & \multicolumn{3}{|c|}{ DV } & \multicolumn{3}{|c|}{ MED } & \multicolumn{3}{|c|}{ IV } & \multicolumn{2}{|c|}{$\begin{array}{c}\text { IV \& } \\
\text { DV }\end{array}$} & \multicolumn{3}{|c|}{ Total } \\
\hline & 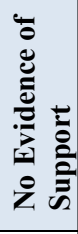 & & है & 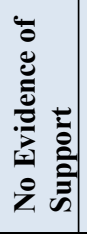 & 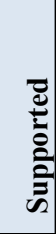 & 苞 & 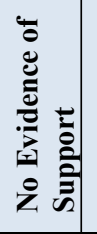 & 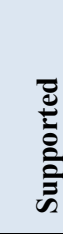 & है & 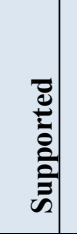 & 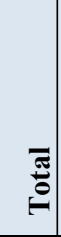 & 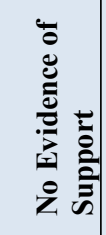 & 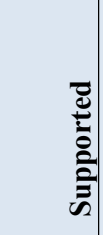 & ڤే \\
\hline $\begin{array}{l}\text { IT } \\
\text { Governance / } \\
\text { Organization }\end{array}$ & 3 & 9 & 12 & & 2 & 2 & 1 & 11 & 12 & 2 & 2 & $\begin{array}{c}4 \\
(19 \% \\
)\end{array}$ & $\begin{array}{c}24 \\
(24 \% \\
)\end{array}$ & $\begin{array}{c}28 \\
(23 \% \\
)\end{array}$ \\
\hline $\begin{array}{l}\text { ERP / } \\
\text { Enterprise } \\
\text { Systems / } \\
\text { Platforms }\end{array}$ & & & & 2 & 4 & 6 & 5 & 12 & 17 & 3 & 3 & $\begin{array}{c}7 \\
(33 \% \\
)\end{array}$ & $\begin{array}{c}19 \\
(19 \% \\
)\end{array}$ & $\begin{array}{c}26 \\
(22 \% \\
)\end{array}$ \\
\hline $\begin{array}{l}\text { Knowledge } \\
\text { Management / } \\
\text { KMS / } \\
\text { Collaborative } \\
\text { Technology }\end{array}$ & & 6 & 6 & & 3 & 3 & 1 & 15 & 16 & 1 & 1 & $\begin{array}{c}1 \\
(5 \%)\end{array}$ & $\begin{array}{c}25 \\
(25 \% \\
\quad)\end{array}$ & $\begin{array}{c}26 \\
(22 \% \\
)\end{array}$ \\
\hline $\begin{array}{l}\text { B2B / E- } \\
\text { commerce / } \\
\text { Internet }\end{array}$ & & 5 & 5 & & & & 7 & 8 & 15 & & & $\begin{array}{c}7 \\
(33 \% \\
) \\
\end{array}$ & $\begin{array}{c}13 \\
(13 \% \\
) \\
\end{array}$ & $\begin{array}{c}20 \\
(17 \% \\
)\end{array}$ \\
\hline $\begin{array}{l}\mathrm{DW} / \mathrm{BI} / \\
\mathrm{DSS} / \mathrm{CRM}\end{array}$ & & & & & & & 1 & 9 & 10 & & & $\begin{array}{c}1 \\
(5 \%) \\
\end{array}$ & $\begin{array}{c}9 \\
(9 \%) \\
\end{array}$ & $\begin{array}{c}10 \\
(8 \%)\end{array}$ \\
\hline Other & & 2 & 2 & & & & & 3 & 3 & & & $\begin{array}{c}0 \\
(0 \%) \\
\end{array}$ & $\begin{array}{c}5 \\
(5 \%) \\
\end{array}$ & $\begin{array}{c}5 \\
(4 \%) \\
\end{array}$ \\
\hline $\begin{array}{l}\text { Software } \\
\text { Development }\end{array}$ & & & & & & & 1 & 4 & 5 & & & $\begin{array}{c}1 \\
(5 \%) \\
\end{array}$ & $\begin{array}{c}4 \\
(4 \%) \\
\end{array}$ & $\begin{array}{c}5 \\
(4 \%) \\
\end{array}$ \\
\hline TOTAL & 3 & 22 & 25 & 2 & 9 & 11 & 16 & 62 & 78 & 6 & 6 & 21 & 99 & 120 \\
\hline
\end{tabular}

Table 7. Analysis of Supported Hypotheses Collected from ACAP in IS Research Papers CrossTabulated with the Technical and Behavioral Domains of the Source Paper for the Respective Hypotheses

\begin{tabular}{|c|c|r|r|r|r|r|r|}
\hline \multirow{2}{*}{ Behavioural Domain } & Technical Domain & IV & DV & MED & $\begin{array}{c}\text { IV \& } \\
\text { DV }\end{array}$ & Total & \multicolumn{1}{c|}{$\%$} \\
\hline & ERP / Enterprise Systems / Platforms & 3 & & 4 & & 7 & $7 \%$ \\
\cline { 2 - 7 } & Other & 2 & 2 & & & 4 & $4 \%$ \\
\cline { 2 - 7 } & IT Governance / Organization & 2 & 2 & & & 4 & $4 \%$ \\
\cline { 2 - 7 } $\begin{array}{c}\text { Adoption / Implementation } \\
\text { Integration }\end{array}$ & DW / BI / DSS / CRM & 3 & & & & 3 & $3 \%$ \\
\cline { 2 - 7 } & B2B / E-commerce / Internet & 3 & & & & 3 & $3 \%$ \\
\hline \multicolumn{2}{|c|}{ Adoption / Implementation / Integration } & 13 & 4 & 4 & 0 & 21 & $21 \%$ \\
\hline
\end{tabular}




\begin{tabular}{|c|c|c|c|c|c|c|c|}
\hline \multirow{3}{*}{$\begin{array}{c}\text { Innovation / Organizational } \\
\text { Performance }\end{array}$} & $\begin{array}{c}\text { Knowledge Management / KMS / } \\
\text { Collaborative Technology }\end{array}$ & 9 & & 1 & 1 & 11 & $11 \%$ \\
\hline & IT Governance / Organization & 3 & 1 & & & 4 & $4 \%$ \\
\hline & Software Development & 1 & & & & 1 & $1 \%$ \\
\hline \multicolumn{2}{|c|}{ Innovation / Organizational Performance } & 13 & 1 & 1 & 1 & 16 & $16 \%$ \\
\hline \multirow{5}{*}{$\begin{array}{l}\text { Knowledge Transfer / } \\
\text { Sharing / Creation }\end{array}$} & $\begin{array}{c}\text { Knowledge Management / KMS / } \\
\text { Collaborative Technology }\end{array}$ & 5 & 6 & 1 & & 12 & $12 \%$ \\
\hline & ERP / Enterprise Systems / Platforms & 5 & & & & 5 & $5 \%$ \\
\hline & IT Governance / Organization & 1 & & 2 & 1 & 4 & $4 \%$ \\
\hline & B2B / E-commerce / Internet & 2 & & & & 2 & $2 \%$ \\
\hline & Software Development & 2 & & & & 2 & $2 \%$ \\
\hline \multicolumn{2}{|c|}{ Knowledge Transfer / Sharing / Creation } & 15 & 6 & 3 & 1 & 25 & $25 \%$ \\
\hline \multirow{5}{*}{$\begin{array}{l}\text { Other (Includes Offshoring / } \\
\text { Outsourcing) }\end{array}$} & DW / BI / DSS / CRM & 4 & & & & 4 & $4 \%$ \\
\hline & IT Governance / Organization & & 3 & & & 3 & $3 \%$ \\
\hline & B2B / E-commerce / Internet & 1 & 1 & & & 2 & $2 \%$ \\
\hline & $\begin{array}{c}\text { Knowledge Management / KMS / } \\
\text { Collaborative Technology }\end{array}$ & 1 & & 1 & & 2 & $2 \%$ \\
\hline & Other & 1 & & & & 1 & $1 \%$ \\
\hline \multicolumn{2}{|c|}{ Other (Includes Offshoring / Outsourcing) } & 7 & 4 & 1 & 0 & 12 & $12 \%$ \\
\hline \multirow{5}{*}{ Utilization } & IT Governance / Organization & 5 & 3 & & 1 & 9 & $9 \%$ \\
\hline & ERP / Enterprise Systems / Platforms & 4 & & & 3 & 7 & $7 \%$ \\
\hline & B2B / E-commerce / Internet & 2 & 4 & & & 6 & $6 \%$ \\
\hline & DW / BI / DSS / CRM & 2 & & & & 2 & $2 \%$ \\
\hline & Software Development & 1 & & & & 1 & $1 \%$ \\
\hline \multicolumn{2}{|c|}{ Utilization } & 14 & 7 & 0 & 4 & 25 & $25 \%$ \\
\hline \multicolumn{2}{|r|}{ TOTAL } & 62 & 22 & 9 & 6 & 99 & $100 \%$ \\
\hline
\end{tabular}

Table 8. Summary of Propositions Collected from ACAP in IS Research Papers

\begin{tabular}{|l|c|c|}
\hline $\begin{array}{c}\text { Count of } \\
\text { Propositions }\end{array}$ & Proposition is supported & \% \\
\cline { 1 - 1 } ACAP cast as & 24 & $52 \%$ \\
\hline DV & 6 & $13 \%$ \\
\hline MED & 3 & $7 \%$ \\
\hline MED \& DV & 9 & $20 \%$ \\
\hline IV & 4 & $9 \%$ \\
\hline IV \& DV & $\mathbf{4 6}$ & $\mathbf{1 0 0 \%}$ \\
\hline \multicolumn{1}{|c|}{ Total } & & \\
\hline
\end{tabular}


Table 9. Cross-Tabulation of Data Analysis Method and Propositions Collected from ACAP in IS Research Papers

\begin{tabular}{|l|c|c|c|c|}
\hline \multirow{2}{*}{\multicolumn{1}{c|}{ ACAP Cast As }} & \multicolumn{2}{|c|}{ Data Analysis } & \multirow{3}{*}{} & \\
\cline { 2 - 3 } & Qualitative & Quantitative & Total & \\
\hline DV & 19 & 5 & 24 & $52 \%$ \\
\hline MED & 3 & 3 & 6 & $13 \%$ \\
\hline MED \& DV & 2 & 1 & 3 & $7 \%$ \\
\hline IV & 9 & & 9 & $20 \%$ \\
\hline IV \& DV & 4 & & 4 & $9 \%$ \\
\hline Total & $\mathbf{3 7}$ & $\mathbf{9}$ & $\mathbf{4 6}$ & $\mathbf{1 0 0}$ \\
\hline Percentage & $\mathbf{8 0 \%}$ & $\mathbf{2 0 \%}$ & & \\
\hline
\end{tabular}

Table 10. Analysis of Supported Propositions Collected from ACAP in IS Research Papers CrossTabulated with the Technical Domain of the Source Paper for the Propositions

\begin{tabular}{|l|c|c|c|c|c|c|c|}
\hline \multicolumn{1}{|c|}{\begin{tabular}{c} 
ACAP Cast As \\
\multicolumn{1}{|c|}{ Technical Domain }
\end{tabular}} & DV & MED & IV & $\begin{array}{c}\text { MED } \\
\text { \& DV }\end{array}$ & $\begin{array}{c}\text { IV \& } \\
\text { DV }\end{array}$ & Total & \% \\
\hline $\begin{array}{l}\text { Knowledge Management / KMS / Collaborative } \\
\text { Technology }\end{array}$ & 14 & 4 & 2 & 3 & 3 & 26 & $57 \%$ \\
\hline ERP / Enterprise Systems / Platforms & 6 & 2 & 5 & & 1 & 14 & $30 \%$ \\
\hline Other & 4 & & & & & 4 & $9 \%$ \\
\hline Software Development & & & 2 & & & 2 & $4 \%$ \\
\hline Total & $\mathbf{2 4}$ & $\mathbf{6}$ & $\mathbf{9}$ & $\mathbf{3}$ & $\mathbf{4}$ & $\mathbf{4 6}$ & $\mathbf{1 0 0 \%}$ \\
\hline Percentage & $\mathbf{5 2 \%}$ & $\mathbf{1 3 \%}$ & $\mathbf{2 0 \%}$ & $\mathbf{7 \%}$ & $\mathbf{9 \%}$ & $\mathbf{1 0 0 \%}$ & \\
\hline
\end{tabular}

Table 11. Analysis of Supported Propositions Collected from ACAP in IS Research Papers CrossTabulated with the Technical and Behavioral Domain of the Source Paper for the Propositions

\begin{tabular}{|l|c|c|c|c|c|c|c|c|}
\hline Behavioral Domain & \multicolumn{1}{|c|}{ Technical Domain } & MED & DV & $\begin{array}{c}\text { IV \& } \\
\text { DV }\end{array}$ & IV & $\begin{array}{c}\text { MED \& } \\
\text { DV }\end{array}$ & Total & \% \\
\hline $\begin{array}{l}\text { Adoption / } \\
\text { Implementation / } \\
\text { Integration }\end{array}$ & $\begin{array}{l}\text { ERP / Enterprise Systems / } \\
\text { Platforms }\end{array}$ & & & & & & \\
\hline Adoption / Implementation / Integration & & & & & & $\mathbf{1}$ & $\mathbf{2 \%}$ \\
\hline $\begin{array}{l}\text { Innovation / } \\
\text { Organizational } \\
\text { Performance }\end{array}$ & $\begin{array}{l}\text { ERP / Enterprise Systems / } \\
\text { Platforms }\end{array}$ & & & & & & \\
\hline Innovation / Organizational Performance & & & & & & & $\mathbf{1 1}$ & $\mathbf{2 4 \%}$ \\
\hline $\begin{array}{l}\text { Knowledge Transfer / } \\
\text { Sharing / Creation }\end{array}$ & $\begin{array}{l}\text { Knowledge Management / } \\
\text { KMS / Collaborative }\end{array}$ & & & & & & & \\
\hline Technology & 4 & 14 & 3 & 2 & 3 & & $\mathbf{2 6}$ & $\mathbf{5 7 \%}$ \\
\hline
\end{tabular}


Other (Includes

Offshoring/

Outsourcing)

\begin{tabular}{|c|c|c|c|c|c|c|c|}
\hline Software Development & & & & 2 & & 2 & \\
\hline Other & & 4 & & & & 4 & \\
\hline $\begin{array}{l}\text { ERP / Enterprise Systems / } \\
\text { Platforms }\end{array}$ & & & & 1 & & 1 & \\
\hline oring / Outsourcing) & & & & & & 7 & $15 \%$ \\
\hline $\begin{array}{l}\text { ERP / Enterprise Systems / } \\
\text { Platforms }\end{array}$ & 1 & & & & & & \\
\hline & & & & & & 1 & $2 \%$ \\
\hline & 6 & 24 & 4 & 9 & 3 & 46 & $100 \%$ \\
\hline & $13 \%$ & $52 \%$ & $9 \%$ & $20 \%$ & $7 \%$ & $100 \%$ & \\
\hline
\end{tabular}

Table 12. Analysis of Measurement Instruments Collected from ACAP in IS Research Papers Cross-Tabulated with the Source Paper

\begin{tabular}{|c|c|c|c|c|c|c|c|}
\hline Measure Distribution & \multicolumn{5}{|c|}{$\begin{array}{c}\text { What aspect of ACAP is the } \\
\text { question attempting to measure? }\end{array}$} & \multirow[b]{2}{*}{ Total } & \multirow[b]{2}{*}{$\%$} \\
\hline Measurement Source Author & 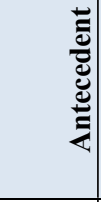 & 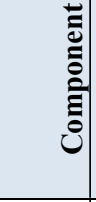 & 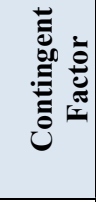 & 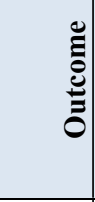 & 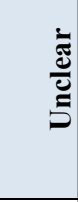 & & \\
\hline Multi & 27 & 64 & & 2 & & 93 & $35 \%$ \\
\hline G. Szulanski (1996) & 31 & 12 & & 1 & & 44 & $17 \%$ \\
\hline Not Clear or Unspecified & 10 & 7 & & 4 & 1 & 22 & $8 \%$ \\
\hline J.J.P. Jansen; F.A.J. Van Den Bosch; H.W. Volberda (2005) & & 21 & & & & 21 & $8 \%$ \\
\hline J.-H. Park; H.-J. Suh; H.-D. Yang (2007) & 5 & 13 & & & & 18 & $7 \%$ \\
\hline A. Malhotra; S. Gosain; O.A. El Sawy (2005) & & & & 13 & & 13 & $5 \%$ \\
\hline P.A. Pavlou; O.A. El Sawy (2006) & 1 & 8 & & 1 & & 10 & $4 \%$ \\
\hline S.A. Zahra; G. George (2002) & & 13 & & 2 & & 15 & $6 \%$ \\
\hline A.C. Boynton; R.W. Zmud; G.C. Jacobs (1994) & 2 & 3 & & & & 5 & $2 \%$ \\
\hline S.W. Chou; A.A. Techatassanasoontorn; I.H. Hung (2015) & 1 & 3 & & & & 4 & $2 \%$ \\
\hline N.L. Díaz-Díaz; P. De Saá-Pérez (2014) & 1 & 1 & 1 & 1 & & 4 & $2 \%$ \\
\hline H.-T.Tsou; J.S. Chen (2012) & & 4 & & & & 4 & $2 \%$ \\
\hline A.N. Mishra; P. Konana; A. Barua (2007) & & & & & 3 & 3 & $1 \%$ \\
\hline A. Tiwana; E.R. McLean (2005) & 2 & 1 & & & & 3 & $1 \%$ \\
\hline W.M. Cohen; D.A. Levinthal (1990) & & 3 & & & & 3 & $1 \%$ \\
\hline G. Martín-de Castro; P. López-Sáez; M. Delgado-Verde (2011) & & & & 1 & & 1 & $0 \%$ \\
\hline Grand Total & 80 & 153 & 1 & 25 & 4 & 263 & $100 \%$ \\
\hline Percentage & $30 \%$ & $58 \%$ & $\mathbf{0 \%}$ & $10 \%$ & $2 \%$ & $100 \%$ & \\
\hline
\end{tabular}


Table 13. Analysis of the Implied Conceptualization of Measurement Instruments Collected from ACAP in IS Research Papers Cross-Tabulated with the Aspect of ACAP the Instrument is Attempting to Measure

\begin{tabular}{|c|c|c|c|c|c|c|c|}
\hline \multirow[t]{2}{*}{$\begin{array}{l}\text { Number of } \\
\text { Measures }\end{array}$} & \multicolumn{5}{|c|}{ What aspect of ACAP is the question attempting to measure? } & \multirow[b]{2}{*}{ Total } & \multirow[b]{2}{*}{$\%$} \\
\hline & Antecedent & Component & $\begin{array}{c}\text { Contingent } \\
\text { Factor } \\
\end{array}$ & Outcome & Unclear & & \\
\hline Capability & 35 & 141 & 1 & 8 & 3 & 188 & $71 \%$ \\
\hline Asset & 45 & 11 & & 17 & & 73 & $28 \%$ \\
\hline Unclear & & 1 & & & 1 & 2 & $1 \%$ \\
\hline Grand Total & 80 & 153 & 1 & 25 & 4 & 263 & $\begin{array}{c}100 \\
\%\end{array}$ \\
\hline Percentage & $30 \%$ & $58 \%$ & $0 \%$ & $10 \%$ & $2 \%$ & $\begin{array}{l}100 \\
\%\end{array}$ & \\
\hline
\end{tabular}

Table 14. Cross-Tabulation between Measurement Source Author and Measurement Conceptualization

\begin{tabular}{|c|c|c|c|c|c|}
\hline \multirow{2}{*}{$\begin{array}{c}\text { Measure Distribution } \\
\text { Measurement Source Author }\end{array}$} & \multicolumn{3}{|c|}{$\begin{array}{c}\text { Measure Conceptualization } \\
\text { Implication: Asset or Capability }\end{array}$} & \multirow[b]{2}{*}{ Total } & \multirow[b]{2}{*}{$\%$} \\
\hline & Asset & Capability & Unclear & & \\
\hline Multi & 15 & 77 & 1 & 93 & $35 \%$ \\
\hline G. Szulanski (1996) & 26 & 18 & & 44 & $17 \%$ \\
\hline Not Clear or Unspecified & 10 & 11 & 1 & 22 & $8 \%$ \\
\hline J.J.P. Jansen; F.A.J. Van Den Bosch; H.W. Volberda (2005) & 1 & 20 & & 21 & $8 \%$ \\
\hline J.-H. Park; H.-J. Suh; H.-D. Yang (2007) & 2 & 16 & & 18 & $7 \%$ \\
\hline A. Malhotra; S. Gosain; O.A. El Sawy (2005) & 7 & 6 & & 13 & $5 \%$ \\
\hline P.A. Pavlou; O.A. El Sawy (2006) & 1 & 9 & & 10 & $4 \%$ \\
\hline S.A. Zahra; G. George (2002) & 4 & 11 & & 15 & $6 \%$ \\
\hline A.C. Boynton; R.W. Zmud; G.C. Jacobs (1994) & 2 & 3 & & 5 & $2 \%$ \\
\hline S.W. Chou; A.A. Techatassanasoontorn; I.H. Hung (2015) & 2 & 2 & & 4 & $2 \%$ \\
\hline N.L. Díaz-Díaz; P. De Saá-Pérez (2014) & 2 & 2 & & 4 & $2 \%$ \\
\hline H.-T.Tsou; J.S. Chen (2012) & & 4 & & 4 & $2 \%$ \\
\hline A.N. Mishra; P. Konana; A. Barua (2007) & & 3 & & 3 & $1 \%$ \\
\hline A. Tiwana; E.R. McLean (2005) & & 3 & & 3 & $1 \%$ \\
\hline W.M. Cohen; D.A. Levinthal (1990) & & 3 & & 3 & $1 \%$ \\
\hline $\begin{array}{l}\text { G. Martín-de Castro; P. López-Sáez; M. Delgado-Verde } \\
\text { (2011) }\end{array}$ & 1 & & & 1 & $0 \%$ \\
\hline Grand Total & 73 & 188 & 2 & 263 & $100 \%$ \\
\hline Percentage & $28 \%$ & $71 \%$ & $1 \%$ & $100 \%$ & \\
\hline
\end{tabular}


Table 15. Cross-Tabulation between Measurement Source Author and ACAP Aspect for Asset Conceptualization

\begin{tabular}{|c|c|c|c|c|c|}
\hline \multirow[b]{2}{*}{ Measurement Source Author } & \multicolumn{3}{|c|}{$\begin{array}{l}\text { What aspect of ACAP is the question attempting } \\
\text { to measure? }\end{array}$} & \multirow{2}{*}{$\begin{array}{c}\text { Grand } \\
\text { Total }\end{array}$} & \multirow[b]{2}{*}{$\%$} \\
\hline & Antecedent & Component & Outcome & & \\
\hline G. Szulanski (1996) & 21 & 4 & 1 & 26 & $36 \%$ \\
\hline Multi & 12 & 3 & & 15 & $21 \%$ \\
\hline Not Clear or Unspecified & 6 & & 4 & 10 & $14 \%$ \\
\hline A. Malhotra; S. Gosain; O.A. El Sawy (2005) & & & 7 & 7 & $10 \%$ \\
\hline A.C. Boynton; R.W. Zmud; G.C. Jacobs (1994) & 2 & & & 2 & $3 \%$ \\
\hline $\begin{array}{l}\text { S.W. Chou; A.A. Techatassanasoontorn; I.H. } \\
\text { Hung (2015) }\end{array}$ & 1 & 1 & & 2 & $3 \%$ \\
\hline J.-H. Park; H.-J. Suh; H.-D. Yang (2007) & 2 & & & 2 & $3 \%$ \\
\hline N.L. Díaz-Díaz; P. De Saá-Pérez (2014) & 1 & & 1 & 2 & $3 \%$ \\
\hline S.A. Zahra; G. George (2002) & & 2 & 2 & 4 & $6 \%$ \\
\hline $\begin{array}{l}\text { J.J.P. Jansen; F.A.J. Van Den Bosch; H.W. } \\
\text { Volberda (2005) }\end{array}$ & & 1 & & 1 & $1 \%$ \\
\hline $\begin{array}{l}\text { G. Martín-de Castro; P. López-Sáez; } \quad \text { M. } \\
\text { Delgado-Verde (2011) }\end{array}$ & & & 1 & 1 & $1 \%$ \\
\hline P.A. Pavlou; O.A. El Sawy (2006) & & & 1 & 1 & $1 \%$ \\
\hline Grand Total & 45 & 11 & 17 & 73 & $100 \%$ \\
\hline Percentage & $62 \%$ & $15 \%$ & $23 \%$ & $100 \%$ & \\
\hline
\end{tabular}

Table 16. Szulanski's (1996) Original Measurement Questions

\begin{tabular}{|l|l|l|}
\hline \multicolumn{1}{|c|}{ Original Measurement Questions } & \multicolumn{1}{|c|}{$\begin{array}{c}\text { Measurement } \\
\text { Implication }\end{array}$} & ACAP Component \\
\hline $\begin{array}{l}\text { Members of }<\text { recipient }>\text { have a common language } \\
\text { to deal with the }<\text { practice }>\text {; }\end{array}$ & Asset & Prior Knowledge \\
\hline $\begin{array}{l}<\text { recipient }>\text { had a vision of what it was trying to } \\
\text { achieve through the transfer; }\end{array}$ & Capability & Recognize the Value \\
\hline $\begin{array}{l}<\text { recipient }>\text { had information on the state-of-the-art } \\
\text { of the }<\text { practice }>\text {; }\end{array}$ & Asset & Prior Knowledge \\
\hline $\begin{array}{l}<\text { recipient }>\text { had a clear division of roles and } \\
\text { responsibilities to implement the }<\text { practice }>\text {; }\end{array}$ & Capability & Org Structure \\
\hline $\begin{array}{l}<\text { recipient }>\text { had the necessary skills to implement } \\
\text { the }<\text { practice }>\text {; }\end{array}$ & Asset & Prior Knowledge \\
\hline $\begin{array}{l}<\text { recipient }>\text { had the technical competence to } \\
\text { absorb the }<\text { practice }>\text {; }\end{array}$ & Asset & Prior Knowledge \\
\hline $\begin{array}{l}<\text { recipient }>\text { had the managerial competence to } \\
\text { absorb the }<\text { practice }>\text {; }\end{array}$ & Capability & Management Cognition \\
\hline
\end{tabular}




\begin{tabular}{|l|l|l|}
$\begin{array}{l}\text { It is well known who can best exploit new } \\
\text { information about the <practice }>\text { within } \\
\text { <recipient }>\text {; }\end{array}$ & Capability & Org Structure \\
\hline $\begin{array}{l}\text { It is well known who can help solve problems } \\
\text { associated with the }<\text { practice }>\end{array}$ & Capability & Org Structure \\
\hline
\end{tabular}

Table 17. Proposed Modified Measurement Questions based on Szulanski (1996)

\begin{tabular}{|l|l|l|}
\hline \multicolumn{1}{|c|}{ Modified Questions } & \multicolumn{1}{|c|}{$\begin{array}{c}\text { Measurement } \\
\text { Implication }\end{array}$} & ACAP Component \\
\hline $\begin{array}{l}\text { Members of }<\text { recipient }>\text { have the ability to deal } \\
\text { with the }<\text { practice }>\text { due to a common language; }\end{array}$ & Capability & Prior Knowledge \\
\hline $\begin{array}{l}<\text { recipient }>\text { had a vision of what it was trying to } \\
\text { achieve through the transfer; }\end{array}$ & Capability & Recognize the Value \\
\hline $\begin{array}{l}\text { <recipient }>\text { had information on the state-of-the-art } \\
\text { of the }<\text { practice }>\text {; }\end{array}$ & Asset & Prior Knowledge \\
\hline $\begin{array}{l}<\text { recipient }>\text { had a clear division of roles and } \\
\text { responsibilities to implement the }<\text { practice>; }\end{array}$ & Capability & Org Structure \\
\hline $\begin{array}{l}\text { With the necessary skills, <recipient }>\text { are able to } \\
\text { implement the }<\text { practice }>\text {; }\end{array}$ & Capability & Prior Knowledge \\
\hline $\begin{array}{l}<\text { recipient }>\text { has the capability to absorb the } \\
<\text { practice }>\text { due to technical competency; }\end{array}$ & Capability & Prior Knowledge \\
\hline $\begin{array}{l}<\text { recipient }>\text { had the managerial competence to } \\
\text { absorb the }<\text { practice }>\text {; }\end{array}$ & Capability & Management Cognition \\
\hline $\begin{array}{l}\text { It is well known who can best exploit new } \\
\text { information about the <practice }> \\
<\text { recipient }>\text {;ithin }\end{array}$ & Capability & Org Structure \\
\hline $\begin{array}{l}\text { It is well known who can help solve problems } \\
\text { associated with the }<\text { practice }>\end{array}$ & Capability & Org Structure \\
\hline
\end{tabular}


Table 18. List of Measures in IS research

\begin{tabular}{|c|c|c|}
\hline ACAP Model Components & Extracted Measures & Origin \\
\hline \multicolumn{3}{|c|}{ Antecedents } \\
\hline \multirow{2}{*}{ Combinative Capabilities } & $\begin{array}{l}\text { Able to create cross-functional task forces to solve urgent } \\
\text { business problems }\end{array}$ & C. Francalanci; V. Morabito (2008) \\
\hline & $\begin{array}{l}\text { Overall, members of this team can interrelate to each other's } \\
\text { unique skills and abilities }\end{array}$ & A. Tiwana; E. R. McLean (2005) \\
\hline \multirow{3}{*}{ Environmental Conditions } & $\begin{array}{l}\text { I knew the reputations of the ERP consulting firm before my } \\
\text { company adopted the ERP system }\end{array}$ & \multirow{3}{*}{$\begin{array}{l}\text { J.-H. Park; H.-J. Suh; H.-D. Yang } \\
\text { (2007) }\end{array}$} \\
\hline & $\begin{array}{l}\text { I knew the careers and reputations of the ERP consultants } \\
\text { before my company adopted the ERP system }\end{array}$ & \\
\hline & $\begin{array}{l}\text { I knew the after-sales services that the ERP consultants } \\
\text { would provide before my company adopted the ERP system }\end{array}$ & \\
\hline Individual Knowledge Sharing & $\begin{array}{l}\text { Our company provides ERP training opportunities to } \\
\text { employees on a regular basis. }\end{array}$ & $\begin{array}{l}\text { H. Liang; N. Saraf; Q. Hu; Y. Xue } \\
\text { (2007) }\end{array}$ \\
\hline $\begin{array}{l}\text { Knowledge } \\
\text { Source/Complementarity }\end{array}$ & $\begin{array}{l}\text { A separate group of personnel that could be labeled as } \\
\text { "technical specialists", }\end{array}$ & \multirow{3}{*}{$\begin{array}{l}\text { S. J. Harrington; T. Guimaraes } \\
(2005)\end{array}$} \\
\hline \multirow{3}{*}{ Learning Relationships } & Frequent use of unscheduled meetings and special studies & \\
\hline & Frequent use of standard, quantitative reports & \\
\hline & $\begin{array}{l}\text { We are good at learning new things within the IT } \\
\text { department. }\end{array}$ & $\begin{array}{l}\text { C. Riemenschneider; M. Allen; D. } \\
\text { Armstrong; M. Reid (2010) }\end{array}$ \\
\hline Management Cognition & $\begin{array}{l}\text { Prior to implementing [insert open source technology } \\
\text { name] ... we had the managerial competence to absorb ... }\end{array}$ & \\
\hline Organization Structure & $\begin{array}{l}\text { Prior to implementing [insert open source technology } \\
\text { name] ... we had a clear division of roles and } \\
\text { responsibilities to implement.... }\end{array}$ & $\begin{array}{l}\text { I. Chengalur-Smith; S. Nevo; P. } \\
\text { Demertzoglou (2010) }\end{array}$ \\
\hline \multicolumn{3}{|c|}{ ACAP } \\
\hline Acquire & $\begin{array}{l}\text { In my company, employees are used to acquiring new skills } \\
\text { by attending training courses }\end{array}$ & C. Francalanci; V. Morabito (2008) \\
\hline
\end{tabular}

Page 40 of 43 


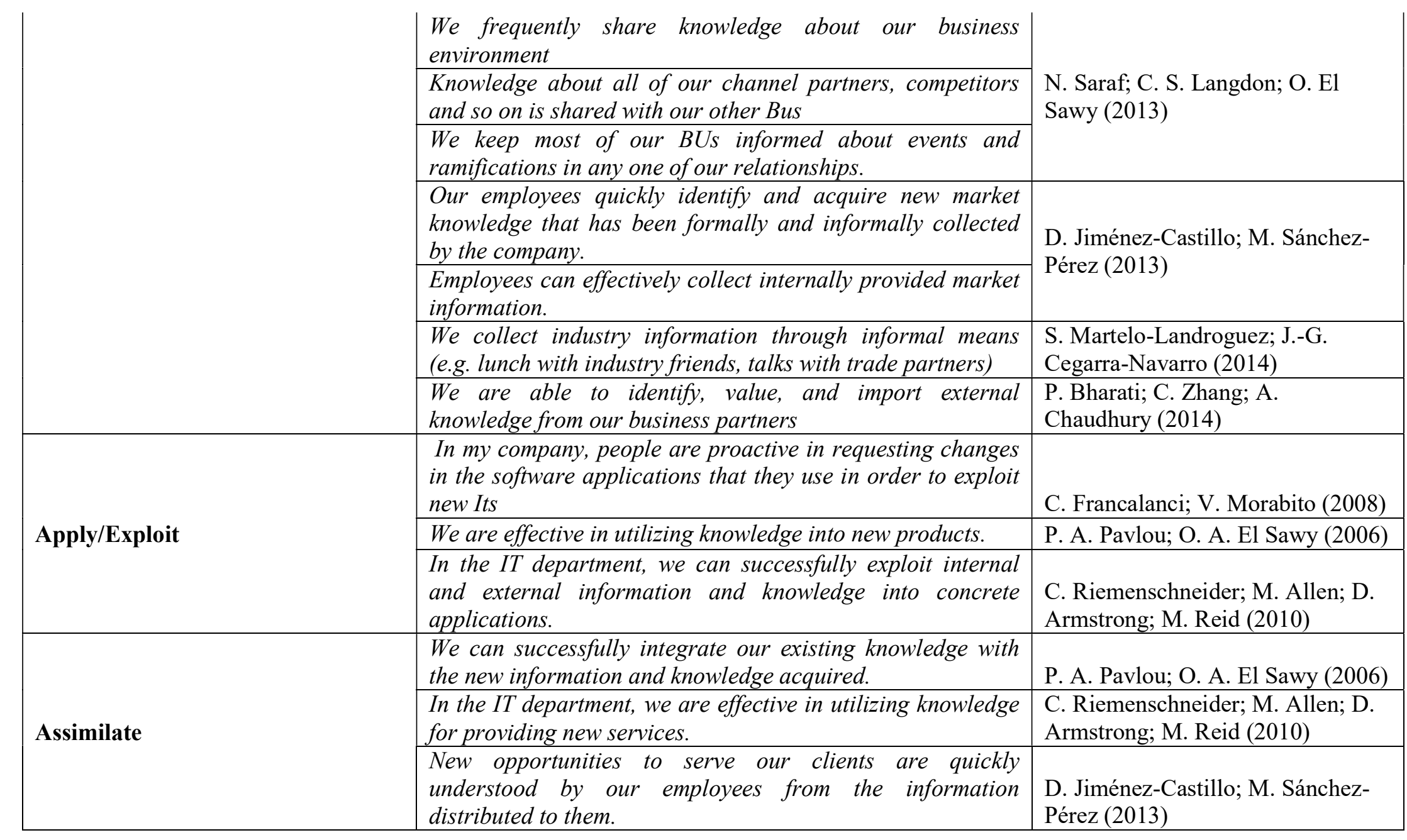

Page 41 of 43 


\begin{tabular}{|c|c|c|}
\hline & $\begin{array}{l}\text { I can successfully integrate our existing knowledge with the } \\
\text { new information and knowledge acquired. }\end{array}$ & \begin{tabular}{|l} 
T.-C. Lin; Y.-C. Ku; Y.-S. Huang \\
(2014)
\end{tabular} \\
\hline & $\begin{array}{l}\text { Our firm encourages the employees to assimilate external IT } \\
\text { knowledge and transform it to professional knowledge } \\
\text { related to the outsourced task. }\end{array}$ & $\begin{array}{l}\text { S. W. Chou; A. A. } \\
\text { Techatassanasoontorn; I. H. Hung } \\
(2015)\end{array}$ \\
\hline \multirow{3}{*}{ PACAP/ RACAP } & $\begin{array}{l}\text { Our company obtained enough knowledge about using ERP } \\
\text { from the ERP vendor. }\end{array}$ & \multirow{3}{*}{$\begin{array}{l}\text { N. Saraf; H. Liang; Y. Xue; Q. Hu } \\
\text { (2013) }\end{array}$} \\
\hline & $\begin{array}{l}\text { Our company provided ERP training opportunities to } \\
\text { employees on a regular basis. }\end{array}$ & \\
\hline & $\begin{array}{l}\text { The IT department provided specific information for using } \\
\text { different ERP modules. }\end{array}$ & \\
\hline \multirow{3}{*}{ Recognizing The Value } & $\begin{array}{l}\text { (Client Alisha) has a vision of what the implementation of } \\
\text { (Purchasing) module project is trying to achieve }\end{array}$ & $\begin{array}{l}\text { D.-G. Ko; L. J. Kirsch; W. R. King } \\
(2005)\end{array}$ \\
\hline & $\begin{array}{l}\text { I knew the deliverables the ERP consulting firm would } \\
\text { provide before my company adopted the ERP system }\end{array}$ & $\begin{array}{l}\text { J.-H. Park; H.-J. Suh; H.-D. Yang } \\
(2007)\end{array}$ \\
\hline & $\begin{array}{l}\text { Prior to implementing [insert open source technology } \\
\text { name] ... we had a vision of what we were trying to achieve } \\
\text { through the use of ... }\end{array}$ & $\begin{array}{l}\text { I. Chengalur-Smith; S. Nevo; P. } \\
\text { Demertzoglou (2010) }\end{array}$ \\
\hline \multirow{4}{*}{ Transform } & $\begin{array}{l}\text { In my company, people can easily accept a change in their } \\
\text { organizational roles }\end{array}$ & \multirow{3}{*}{ C. Francalanci; V. Morabito (2008) } \\
\hline & $\begin{array}{l}\text { In my company, people are proactive in requesting changes } \\
\text { in the software applications that they use in order to meet } \\
\text { new operating requirements }\end{array}$ & \\
\hline & $\begin{array}{l}\text { My company can quickly adjust production capabilities to } \\
\text { variations of market demands }\end{array}$ & \\
\hline & $\begin{array}{l}\text { Our employees quickly recognize the usefulness of the new } \\
\text { market knowledge that is distributed to them with regard to } \\
\text { their existing knowledge. }\end{array}$ & $\begin{array}{l}\text { D. Jiménez-Castillo; M. Sánchez- } \\
\text { Pérez (2013) }\end{array}$ \\
\hline
\end{tabular}

Page 42 of 43 
Our employees have the ability to combine existing market

knowledge with the newly acquired and

assimilated knowledge provided by the company, with commercial ends.

I am effective in transforming existing information into new T.-C. Lin; Y.-C. Ku; Y.-S. Huang

knowledge.

(2014)

Our unit quickly recognizes the usefulness of new external $\quad$ S. Martelo-Landroguez; J.-G.

knowledge to existing knowledge

Cegarra-Navarro (2014)

We can successfully integrate existing knowledge with new 1 P. Bharati; C. Zhang; A.

\begin{tabular}{l|l} 
knowledge acquired from our business partners & Chaudhury (2014)
\end{tabular} 